\title{
Occupational Exposure to Steady Magnetic Fields and its Effect on Workers Blood Indices at an Electrolysis Unit
}

\author{
Mohammad Reza Ghotbi Ravandi ${ }^{1}$, Hossein Mardi $^{2}$, Narges Khanjani ${ }^{3,4 *}$, and Abolfazl Barkhordari ${ }^{5}$ \\ ${ }^{1}$ Assistant Professor, Department of Occupational Health, School of Public Health, Kerman University of Medical Science, \\ Kerman, Iran \\ ${ }^{2}$ MSc Student, Department of Occupational Health, School of Public Health, Kerman University of Medical Sciences, Kerman, Iran \\ ${ }^{3}$ Associate Professor, Environmental Health Engineering Research Center, Kerman University of Medical Sciences, Kerman, Iran \\ ${ }^{4}$ Honorary Research Fellow, Monash Centre for Occupational and Environmental Health, School of Public Health and \\ Preventive Medicine, Monash University, Melbourne, Australia \\ ${ }^{5}$ Assistant Professor, Department of Occupational Health, School of Public Health, Shahid Sadoughi University of Medical Science, \\ Yazd, Iran
}

(Received 13 October 2015, Received in final form 4 April 2016, Accepted 5 April 2016)

\begin{abstract}
The health effects of environmental and occupational exposure to steady magnetic fields is a matter of concern. The aim of this study was to evaluate the hematologic effects of exposure to steady magnetic fields at the electrolysis unit of a Copper complex. The population under study was the workers of the electrolysis unit of the copper refinery. The average steady magnetic field in the exposure group was $2.5 \mathrm{mT}$. The blood indices of workers exposure to steady magnetic fields after adjusting for confounders showed decreased white blood cells (except neutrophils) and increase in the number and volume of platelets. Red blood cells did not show any significant difference. Exposure to steady magnetic fields even in proposed safe limits may have hematologic effects on humans. There is a necessity for more research about the safe doses of exposure to magnetic fields.
\end{abstract}

Keywords : steady magnetic fields, occupational exposure, blood indices

\section{Introduction}

Environmental and occupational exposure to electromagnetic fields is increasing due to increased use of electrical equipment in industry and medical procedures [1]. There are studies considering mapping and determining the pollution of electromagnetic fields $[2,3]$. Steady magnetic fields are time independent and with steady intensity. It is hard to protect against these fields as they can easily penetrate biological tissues. Environmental exposure to steady magnetic fields from the earth's natural magnetic field depends on location and is between 0.03 to $0.07 \mathrm{mT}$ [4]. The most important sources for steady magnetic fields include the electrolysis process, welding equipment, medical imaging procedures, and direct current generators and etc [5]. Nowadays most people's exposure to steady magnetic fields happens when

(C)The Korean Magnetics Society. All rights reserved.

*Corresponding author: Tel/Fax: +98-34-3132-5102

e-mail: n_khanjani@kmu.ac.ir they use medical imaging techniques such as Magnetic Resonance Imaging (MRI) [1]. Limited epidemiological studies have been performed about the effects of steady magnetic fields on people's health. The effects of exposure to magnetic fields with intensities more than $2 \mathrm{~T}$ are headache, metal taste, dizziness and vomiting [2]. These effects have not been reported with magnetic fields with less intensity, but in other studies there have been reports about the effects of chronic exposure to steady magnetic fields on the reproductive system and increased cancer incidence in the aluminum electrolysis industry, welding industry and medical imaging centers. Generally using steady magnetic fields in industry and medicine has led to increased exposure to these fields and therefore it seems necessary to do more studies about their effect on human health [6]. Many scientific guidelines have been developed by international organizations including the World Health Organization (WHO) and the International Commission on Non-Ionizing Radiation Protection (ICNIRP) about the non-ionic radiations related to steady magnetic fields [1,4]. These standards show the importance of 
controlling exposure to these magnetic fields.

In the past, epidemiologic studies were mainly done on workers that were exposed to steady magnetic fields produced from direct current electrical equipment. Most workers in the aluminum production industry, welding industry and industries that use electrolyte cells for separating chemicals are in exposure with magnetic fields that are $10 \mathrm{mT}$ in average. The outcomes under study in previous studies were cancer, hematologic parameters, chromosome aberration frequency, reproductive outcomes and musculoskeletal disorders [1].

The American Conference of the Governmental Industrial Hygienists (ACGIH) has suggested that the maximum permissible dose for exposure to steady magnetic fields for the whole body is $60 \mathrm{mT}$ and for the limbs is $600 \mathrm{mT}$ for $8 \mathrm{~h}$ working, and the maximum threshold is respectively 2 and $20 \mathrm{~T}$ for the whole body and limbs. This threshold has also been accepted as the maximum national threshold in Iran [7]. Also the International Commission on Non-ionizing Radiation Protection has suggested that the maximum permissible amount of exposure to steady magnetic fields is $0.2 \mathrm{~T}$. However these values have to be used as a guide for controlling exposure to steady magnetic fields and should not be regarded as the certain cut off point for their side-effects [1].

Considering the fact that there is still debate about the adverse effects of these steady magnetic fields, this study was conducted to evaluate the probable effects of these fields on the blood indices of workers who had worked 7 $\mathrm{h}$ a day and at least 3 years in places exposed to these magnetic fields.

\section{Materials and Methods}

This was an analytical cross-sectional study performed at the Kerman, Sarcheshmeh Copper Complex. This complex is one of the big copper mines in the southeast of Iran. Every year several tons of copper with high purity are exported to other countries. In the copper electrolysis section, the convector and intensifier stations are among the places that workers are exposed to steady magnetic fields for long time intervals.

The workers in electrolysis salons are also exposed to chemicals such as sulfuric acid mists which are lower than the permissible limits for this chemical. The Threshold Limit Value) TLV (for sulfuric acid is $0.1 \mathrm{mg} / \mathrm{m}^{3}$ for an 8 - hours time weighted average [7].

In this section there are a sum of 960 electrolysis cells, in which 50 cells are used for production of the primary cathode and the rest of the cells are used for production of the commercial cathode. Electricity enters the cathode and anode with an intensity of $210 \mathrm{~A} / \mathrm{m}^{2}$, and a voltage of $0.25 \mathrm{~V} \mathrm{DC}$ and produces copper with a purity of $99.99 \%$.

In this study in order to measure the intensity of steady magnetic fields, a personal Magnetic Field Monitor (Model HI-3550 made by Holaday Industries Inc, Eden Prairie, $\mathrm{MN}, 55344$, US) was used. Before starting the measurements, the device was calibrated according to instructions. Measuring magnetic fields was performed according to the IEEE C95.6 method and with the aim of measuring environmental magnetic field intensity (the instant peaks) by using the described device.

The populations under study were workers working at the electrolysis saloon of the Sarcheshmeh copper complex. One hundred workers that were exposed to steady magnetic fields were chosen as the exposed group and 100 workers whom were not exposed to this field were chosen from the workers of the concentrating unit which had similar working conditions (expect exposure to steady magnetic fields).

In the concentration unit mine dust with $1 \%$ copper enters the unit and after getting crushed in a wet environment enters the flotation units. Eventually copper concentration increases to $25-30 \%$ when exiting the concentration unit.

Workers in this complex were also exposed to copper dust including chemicals such as lime, copper and silica (as silicate) which were below the threshold. According to studies these mists do not affect blood indices [7].

Eventually 90 people participated in each group. These workers were exposed to steady magnetic fields except during lunch and prayer hours for about $7 \mathrm{~h}$ a day and at least for 2 to 3 years.

After the workers consented to participate in the study and with the cooperation of the industry's health center, a demographic questionnaire was completed for each person and $1.5 \mathrm{~mL}$ blood was taken and transferred to tubes including the $\mathrm{K}_{2}$ EDTA anticoagulant. Then after coding and blinding, the samples were transferred to the laboratory and were analyzed by a certain technician for blood indices. For statistical analysis the SPSS19 software (SPSS Inc, Chicago, IL) was used and the Mann Whitney $\mathrm{U}$ test, one way ANOVA, chi-square and logistic regression was performed.

The study was approved by the Kerman University of Medical Sciences, Standing Committee on Ethics in Research.

\section{Results and Discussion}

The average intensity of steady magnetic fields in the refinery electrolysis saloon of the Sarcheshmeh copper complex was $2.5 \pm 0.78 \mathrm{mT}$ that was significantly less 
than the permissible international level that was $60 \mathrm{mT}$ $(\mathrm{p}<0.001)$. The mean and standard deviation of age in the exposed and unexposed (control) group was respectively $29.4 \pm 4.5$ and $38.8 \pm 6.8$ years. The age variable was not normally distributed and therefore the Mann Whitney U Test was used for comparing age between the two groups. The median of age between the two groups was statistically significant $(p<0.001)$. For comparing the other demographic variables the chi-square test was used and the differences between some variables were significant. These variables were considered as confounders in the multivariable analysis. The demographic characteristic of the workers have been shown in Table 1.

The blood index variables did not have a normal distribution and the Kolmogorov-Smirnov test was significant. Therefore, in order to study the relationship between the exposed and unexposed groups, the Mann Whitney U Test was used. This test showed that there was a significant difference between the count of neutrophils, lymphocytes, monocytes, eosinophils, basophils, the percentage of neutrophils, monocytes, eosinophils, basophils, platelets, PCT, MPV, $\mathrm{PDW}_{\mathrm{SD}}$ and $\mathrm{PDW}_{\mathrm{CV}}$ between the two groups. These results have been shown in Table 2 .

It seems like exposure to magnetic fields leads to decrease in some types of white blood cells, and increases the count and volume of platelets but does not have any effect on red blood cells.

According to the univariate and multivariate analysis performed for the blood indices even after adjustment, workers with normal leukocytes were less likely to come from the exposed groups. No significant difference in erythrocyte indices was seen between the two groups. Also even after adjustment workers with higher platelet indices were more likely to come from the exposed group. These results have been shown in Table 3 .

Steady magnetic fields are one of the important risk factors threatening the health of workers exposed to these fields. Magnetic and electric fields with different fre-

Table 1. The demographic characteristic of the workers evaluated in this study.

\begin{tabular}{|c|c|c|c|c|}
\hline \multicolumn{2}{|c|}{ Variable } & \multirow{3}{*}{$\begin{array}{c}\begin{array}{c}\text { Exposed } \\
\text { No }(\%)\end{array} \\
25(27.8 \%) \\
65(72.2 \%)\end{array}$} & \multirow{3}{*}{$\begin{array}{c}\text { Un exposed } \\
\text { No }(\%) \\
6(6.7 \%) \\
84(93.3 \%)\end{array}$} & \multirow{3}{*}{$\begin{array}{l}\text { P-value } \\
<0.001\end{array}$} \\
\hline & Single & & & \\
\hline Marital status & Married & & & \\
\hline \multirow{4}{*}{ Education status } & Under diploma & $9(10 \%)$ & $18(20 \%)$ & \multirow{4}{*}{0.655} \\
\hline & Diploma & $69(76.7 \%)$ & $49(54.4 \%)$ & \\
\hline & Graduate certificate & $9(10 \%)$ & $11(12.2 \%)$ & \\
\hline & Bachelor & $3(3.3 \%)$ & $12(13.3 \%)$ & \\
\hline \multirow{5}{*}{ Job satisfaction status } & Very high & $8(8.9 \%)$ & $11(12.2 \%)$ & \multirow{5}{*}{0.065} \\
\hline & High & $10(11.1 \%)$ & $20(22.2 \%)$ & \\
\hline & Moderate & $53(58.9 \%)$ & $49(54.4 \%)$ & \\
\hline & Low & $5(5.6 \%)$ & $9(10 \%)$ & \\
\hline & Very low & $11(12.2 \%)$ & $1(1.1 \%)$ & \\
\hline \multirow{4}{*}{ Residential status } & Rafsenjan & $54(60 \%)$ & $40(44.4 \%)$ & \multirow{4}{*}{0.070} \\
\hline & Shahrebabak & $12(13.3 \%)$ & $23(25.6 \%)$ & \\
\hline & Sirjan & $13(14.4 \%)$ & $9(10 \%)$ & \\
\hline & ShahrakeSarcheshme & $12(12.2 \%)$ & $18(20 \%)$ & \\
\hline \multirow{2}{*}{ Shift work status } & 2 shifts & $45(50.0 \%)$ & $35(40.0 \%)$ & \multirow{2}{*}{0.193} \\
\hline & 4 shifts & $45(50.0 \%)$ & $52(57.8 \%)$ & \\
\hline \multirow{2}{*}{ Smoking status } & Smoker & $9(10 \%)$ & $37(41.1 \%)$ & \multirow{2}{*}{$<0.001$} \\
\hline & Non-smoker & $81(90 \%)$ & $53(58.9 \%)$ & \\
\hline \multirow{4}{*}{ Working history status } & $<5$ years & $61(67.8 \%)$ & $6(6.7 \%)$ & \multirow{4}{*}{$<0.001$} \\
\hline & $5-10$ years & $25(27.8 \%)$ & $21(23.3 \%)$ & \\
\hline & $10-15$ years & $2(2.2 \%)$ & $29(32.2 \%)$ & \\
\hline & $>15$ years & $2(2.2 \%)$ & $34(37.8 \%)$ & \\
\hline \multirow{4}{*}{ Age status } & $<28$ years & $33(36.3 \%)$ & $2(2.2 \%)$ & \multirow{4}{*}{$<0.001$} \\
\hline & $28-32$ years & $29(32.2 \%)$ & $12(13.2 \%)$ & \\
\hline & $32-39$ years & $21(23.3 \%)$ & $34(37.4 \%)$ & \\
\hline & $>39$ years & $3(3.3 \%)$ & $42(46.7 \%)$ & \\
\hline
\end{tabular}


Table 2. The results of blood parameter measurements in the exposed and unexposed groups.

\begin{tabular}{|c|c|c|c|c|c|c|c|c|}
\hline Variable & Groups & Mean $\pm \mathrm{Sd}$ & $\begin{array}{c}25^{\text {th }} \\
\text { percentile }\end{array}$ & Median & $\begin{array}{c}75^{\text {th }} \\
\text { percentile }\end{array}$ & Max & Min & P-value \\
\hline \multirow{2}{*}{$\begin{array}{l}\text { White Blood Cells } \\
\text { (WBC) }\end{array}$} & Non-exposured & $1.5 \pm 6.33$ & 5.37 & 6.09 & 7.08 & 10.97 & 3.41 & \multirow{2}{*}{0.599} \\
\hline & Exposured & $1.74 \pm 6.08$ & 5.17 & 6.14 & 7.13 & 11.16 & 0.01 & \\
\hline \multirow{2}{*}{ Neutrophils } & Non-exposured & $0.68 \pm 1.26$ & 0.73 & 1.18 & 1.8 & 3.19 & 0.05 & \multirow{2}{*}{0.03} \\
\hline & Exposured & $1.29 \pm 1.79$ & 0.52 & 1.84 & 2.61 & 5.03 & 0 & \\
\hline \multirow{2}{*}{ Lymphocytes } & Non-exposured & $1.04 \pm 4.34$ & 3.63 & 4.19 & 4.87 & 7.88 & 2.43 & \multirow{2}{*}{0.01} \\
\hline & Exposured & $1.4 \pm 3.9$ & 3.14 & 3.78 & 4.63 & 7.61 & 0 & \\
\hline \multirow{2}{*}{ Monocyte } & Non-exposured & $0.21 \pm 0.56$ & 0.41 & 0.53 & 0.7 & 1.29 & 0.23 & \multirow{2}{*}{$<0.001$} \\
\hline & Exposured & $0.16 \pm 0.25$ & 0.13 & 0.24 & 0.35 & 0.88 & 0 & \\
\hline \multirow{2}{*}{ Eosinophils } & Non-exposured & $1.09 \pm 0.194$ & 0.13 & 0.17 & 0.25 & 0.65 & 0.05 & \multirow{2}{*}{$<0.001$} \\
\hline & Exposured & $0.08 \pm 0.11$ & 0.06 & 0.1 & 0.15 & 0.38 & 0 & \\
\hline \multirow{2}{*}{ Basophils } & Non-exposured & $0.03 \pm 0.7$ & 0.05 & 0.06 & 0.08 & 0.21 & 0.01 & \multirow{2}{*}{$<0.001$} \\
\hline & Exposured & $0.02 \pm 0.03$ & 0.01 & 0.02 & 0.04 & 0.15 & 0 & \\
\hline \multirow{2}{*}{ \%Neutrophils } & Non-exposured & $8.06 \pm 18.88$ & 11.9 & 18.2 & 25.6 & 37.3 & 1.1 & \multirow{2}{*}{0.003} \\
\hline & Exposured & $17.13 \pm 28.24$ & 11.57 & 28.95 & 42.65 & 67.3 & 1.9 & \\
\hline \multirow{2}{*}{ \%Lymphocytes } & Non-exposured & $7.63 \pm 67.92$ & 62.5 & 67.4 & 73.2 & 85.5 & 49.7 & \multirow{2}{*}{0.361} \\
\hline & Exposured & $17.76 \pm 64.9$ & 48.97 & 64.55 & 81.45 & 91.9 & 27.2 & \\
\hline \multirow{2}{*}{ \%Monocytes } & Non-exposured & $3.32 \pm 9.02$ & 6.7 & 8.4 & 10.5 & 19.2 & 3.5 & \multirow{2}{*}{$<0.001$} \\
\hline & Exposured & $2.37 \pm 4.34$ & 2.4 & 4 & 6.22 & 10.5 & 1 & \\
\hline \multirow{2}{*}{ \%Eosinophils } & Non-exposured & $1.43 \pm 3.01$ & 1.9 & 2.7 & 4.1 & 6.6 & 1 & \multirow{2}{*}{$<0.001$} \\
\hline & Exposured & $1.33 \pm 1.91$ & 0.9 & 1.6 & 2.65 & 6.4 & 0 & \\
\hline \multirow{2}{*}{ \%Basophils } & Non-exposured & $0.52 \pm 1.1$ & 0.8 & 1 & 1.3 & 2.8 & 0.1 & $<00001$ \\
\hline & Exposured & $0.58 \pm 0.54$ & 0.2 & 0.4 & 0.7 & 3.3 & 0 & $<0.001$ \\
\hline Red Blood Cells & Non-exposured & $0.5 \pm 5.51$ & 5.16 & 5.44 & 5.81 & 7.68 & 4.69 & 099 \\
\hline (RBC) & Exposured & $0.67 \pm 5.39$ & 5.22 & 5.49 & 5.7 & 6.09 & 0.01 & 0.99 \\
\hline Hemoglobin Glow Bin & Non-exposured & $1.69 \pm 15.55$ & 14.7 & 15.4 & 16.12 & 25.4 & 12.2 & 0.03 \\
\hline (HGB) & Exposured & $2.21 \pm 15.15$ & 14.67 & 15.4 & 16.1 & 25.4 & 12.2 & 0.93 \\
\hline Hematocrit & Non-exposured & $3.49 \pm 45.98$ & 43.35 & 45.5 & 48.15 & 58.6 & 38.2 & \\
\hline (Hct) & Exposured & $5.41 \pm 44.96$ & 43.4 & 45.6 & 47.6 & 51.1 & 0 & 0.49 \\
\hline Mean Corpuscular Volume & Non-exposured & $5 \pm 83.9$ & 80.3 & 84.7 & 87.2 & 95.5 & 63.9 & 0.058 \\
\hline$(\mathrm{MCV})$ & Exposured & $9.49 \pm 82.35$ & 80.55 & 83.4 & 85.2 & 93.7 & 0 & 0.058 \\
\hline Mean Corpuscular & Non-exposured & $7.38 \pm 28.79$ & 26.87 & 28.25 & 29.22 & 95.5 & 20 & 098 \\
\hline Hemoglobin $(\mathrm{MCH})$ & Exposured & $3.94 \pm 27.73$ & 26.87 & 28.3 & 29.22 & 33.2 & 0 & 0.98 \\
\hline Mean Corpuscular & Non-exposured & $2.3 \pm 33.25$ & 33.2 & 33.95 & 34.5 & 36.2 & 0 & \\
\hline $\begin{array}{l}\text { Hemoglobin Concentration } \\
\text { (MCHC) }\end{array}$ & Exposured & $4.41 \pm 33.29$ & 33.2 & 33.95 & 34.5 & 36.2 & 0 & 0.2 \\
\hline Red Cell Distribution & Non-exposured & $3.75 \pm 33.1$ & 31 & 32.95 & 35.2 & 47.1 & 23.8 & \\
\hline $\begin{array}{l}\text { Width-standard deviation } \\
\text { (RDWsd) }\end{array}$ & Exposured & $11.5 \pm 33.25$ & 30.6 & 32.05 & 34.05 & 132 & 0 & 0.19 \\
\hline Red Cell Distribution & Non-exposured & $3.33 \pm 13.62$ & 12.8 & 13.2 & 13.7 & 44 & 11.8 & 0 \\
\hline (RDWcv) & Exposured & $1.54 \pm 13.04$ & 12.87 & 13.15 & 13.5 & 15.6 & 0 & 0.19 \\
\hline Platelet & Non-exposured & $53.41 \pm 219.28$ & 185 & 215 & 253 & 395 & 100 & 0001 \\
\hline Platelet & Exposured & $85.74 \pm 267.61$ & 223 & 262.5 & 299.75 & 740 & 7 & 0.001 \\
\hline Platelet Crit & Non-exposured & $0.04 \pm 0.19$ & 0.17 & 0.2 & 0.22 & 0.37 & 0.08 & 001 \\
\hline$(\mathrm{PCT})$ & Exposured & $0.1 \pm 0.27$ & 0.23 & 0.27 & 0.31 & 1.01 & 0 & .001 \\
\hline Mean Platelet Volume & Non-exposured & $1.36 \pm 9.16$ & 8.25 & 9.2 & 10.2 & 12.4 & 6.1 & 0001 \\
\hline (MPV) & Exposured & $1.82 \pm 10.34$ & 9.27 & 10.55 & 11.4 & 14.9 & 0 & 0.001 \\
\hline Platelet Distribution Width & Non-exposured & $2.58 \pm 22.46$ & 20.9 & 22.15 & 24.05 & 33.9 & 18 & 0003 \\
\hline (PDW) & Exposured & $23.35 \pm 3.43$ & 21.57 & 23.5 & 25.22 & 29.5 & 0 & 0.005 \\
\hline
\end{tabular}


Table 3. Univariate and multivariate logistic regression analysis adjusted for demographic variables.

\begin{tabular}{|c|c|c|c|c|}
\hline Variable & $\begin{array}{l}\text { Crude OR } \\
(95 \% \mathrm{CI})\end{array}$ & $p$-value & $\begin{array}{c}\text { Adjusted OR } \\
(95 \% \mathrm{CI})\end{array}$ & p-value \\
\hline $\begin{array}{l}\text { WBC } \\
\text { Abnormal }<4.4 \\
\text { Normal 4.4-11 }\end{array}$ & $\begin{array}{c}1 \\
0.37(0.12-0.96)\end{array}$ & 0.04 & $\begin{array}{c}1 \\
0.20(0.04-0.83)\end{array}$ & 0.02 \\
\hline $\begin{array}{l}\text { Neutrophil } \\
\text { Abnormal }<1.8 \\
\text { Normal 1.8-7.8 }\end{array}$ & $3.03(6.28-1.46)$ & 0.003 & $\begin{array}{c}1 \\
2.24(13.44-1.34)\end{array}$ & 0.01 \\
\hline $\begin{array}{l}\text { Lymphocyte } \\
\text { Abnormal }<1 \\
\text { Normal 1-4.8 } \\
\end{array}$ & $\begin{array}{c}1 \\
0.785(1.72-0.35) \\
\end{array}$ & 0.54 & $\begin{array}{c}1 \\
0.55(1.83-0.16)\end{array}$ & 0.33 \\
\hline $\begin{array}{l}\text { Monocyte } \\
\text { Abnormal }<0.8 \\
\text { Normal 0.8-1 }\end{array}$ & $\begin{array}{c}1 \\
0.06(0.55-0.009) \\
\end{array}$ & 0.01 & $\begin{array}{c}1 \\
0.04(0.84-0.002) \\
\end{array}$ & 0.03 \\
\hline $\begin{array}{l}\text { Eosinophil } \\
\text { Abnormal }<0.1 \\
\text { Normal 0.1-0.45 }\end{array}$ & $\begin{array}{c}1 \\
0.22(0.51-0.1)\end{array}$ & $<0.001$ & $\begin{array}{c}1 \\
0.39(1.27-0.11)\end{array}$ & 0.11 \\
\hline $\begin{array}{l}\text { Basophil } \\
\text { Abnormal }<0.1 \\
\text { Normal } 0.1-0.2 \\
\end{array}$ & $\begin{array}{c}1 \\
0.33(0.88-0.12) \\
\end{array}$ & 02 & $\begin{array}{c}1 \\
0.025(0.94-0.06) \\
\end{array}$ & 0.04 \\
\hline $\begin{array}{l}\text { RBC } \\
\text { Abnormal >5.9 } \\
\text { Normal 5.9-4.5 }\end{array}$ & $\begin{array}{c}1 \\
0.22(0.61-0.07)\end{array}$ & $<0.001$ & $\begin{array}{c}1 \\
0.36(1.53-0.08)\end{array}$ & 0.16 \\
\hline $\begin{array}{l}\text { HGB } \\
\text { Abnormal <14 } \\
\text { Normal 14-17.5 }\end{array}$ & $\begin{array}{c}1 \\
1.28(3.41-0.48)\end{array}$ & 0.62 & $\begin{array}{c}1 \\
0.44(1.77-0.11)\end{array}$ & 0.24 \\
\hline $\begin{array}{l}\text { HCT } \\
\text { Abnormal }<14.5 \\
\text { Normal 14.5-50.4 }\end{array}$ & $\begin{array}{c}1 \\
1.22(4.18-0.36) \\
\end{array}$ & .74 & $\begin{array}{c}1 \\
0.17(1.01-0.03) \\
\end{array}$ & 0.06 \\
\hline $\begin{array}{l}\mathrm{MCV} \\
\text { Abnormal }<80 \\
\text { Normal } 80-96 \\
\end{array}$ & $\begin{array}{c}1 \\
0.68(1.47-0.32) \\
\end{array}$ & 0.337 & $\begin{array}{c}1 \\
0.65(1.9-0.22) \\
\end{array}$ & 0.43 \\
\hline $\begin{array}{l}\mathrm{MCH} \\
\text { Abnormal }<27.5 \\
\text { Normal 27.5-33.2 }\end{array}$ & $\begin{array}{c}1 \\
1.35(2.54-0.72)\end{array}$ & .33 & $\begin{array}{c}1 \\
1.14(2.76-0.47)\end{array}$ & 0.77 \\
\hline $\begin{array}{l}\text { MCHC } \\
\text { Abnormal }<33.4 \\
\text { Normal 33.4-35.5 }\end{array}$ & $\begin{array}{c}1 \\
1.57(2.91-0.85)\end{array}$ & .14 & $\begin{array}{c}1 \\
2.01(4.91-0.82)\end{array}$ & 0.12 \\
\hline $\begin{array}{l}\text { RDWsd } \\
\text { Abnormal }<37 \\
\text { Normal 37-54 }\end{array}$ & $\begin{array}{c}1 \\
0.78(2.07-0.29)\end{array}$ & 0.62 & $\begin{array}{c}1 \\
2.21(8.75-0.56)\end{array}$ & 0.25 \\
\hline $\begin{array}{l}\text { RDWcv } \\
\text { Abnormal >14.5 } \\
\text { Normal 14.5-11.5 }\end{array}$ & $\begin{array}{c}1 \\
0.82(2.8-0.24)\end{array}$ & 75 & $\begin{array}{c}1 \\
3.31(18.97-0.57)\end{array}$ & 0.17 \\
\hline $\begin{array}{l}\text { Platelet } \\
\text { Abnormal }<150 \\
\text { Normal 150-450 }\end{array}$ & $\begin{array}{c}1 \\
4.29(20.8-0.88)\end{array}$ & 0.07 & $\begin{array}{c}1 \\
1.91(15.01-0.24)\end{array}$ & 0.53 \\
\hline $\begin{array}{l}\text { PCT } \\
\text { Abnormal }<0.17 \\
\text { Normal } 0.17-0.35\end{array}$ & $\begin{array}{c}1 \\
5.75(17.68-1.87)\end{array}$ & 0.002 & $\begin{array}{c}1 \\
2.32(9.5-0.57)\end{array}$ & 0.23 \\
\hline $\begin{array}{l}\text { MPV } \\
\text { Abnormal }<9 \\
\text { Normal 9-13 }\end{array}$ & $\begin{array}{c}1 \\
2.92(5.68-1.5)\end{array}$ & 0.002 & $\begin{array}{c}1 \\
5.39(14.55-2)\end{array}$ & 0.001 \\
\hline
\end{tabular}

quencies and intensities cause different complications. These complications also vary based on the workers' exposed dose, the usage of personal safety equipment, duration of exposure and distance from source [8]. Also tissues where cells divide more quickly are more susceptible than others [8]. In humans whites cells are produced more frequently and have a shorter life span in comparison to red blood cells [9] and are probably more sensitive to the effects of electromagnetic fields.

The occupational exposure of workers in the electrolysis unit evaluated in this study was less than the permissible national limit. However, it still seems like exposure to this field has led to decrease in the count of leukocytes and increase in the number and volume of platelets.

A study done by Marsh et al confirms our results. In this study the mean intensity of steady magnetic fields that the workers were exposed to was 7.6 to $14.6 \mathrm{mT}$. The results of their study showed that people exposed to steady magnetic fields have lower white cell counts in comparison to the control group, but they did not see an effect on hemoglobin, red blood cells and hematocrit [10]. In Vyalov et al.'s study in the Moscow Scientific Research Institute of Hygiene, exposure to steady magnetic fields with the intensity of 15 to $25 \mathrm{mT}$ was associated with decrease in the count of white blood cells [10, 11]. Also in a study done by Choobineh et al. in the chlorine producing units the percentage of monocytes, eosinophils and neutrophils in the group exposed to steady magnetic fields was less than the unexposed group, and the average count of platelets was significantly higher [12]. However, in a study by Fani et al. in an aluminum electrolysis workshop, in which workers were exposed to magnetic fields from 25 to $32 \mathrm{mT}$, the average blood indices after two years exposure in different classes of white blood cells, neutrophils, red blood cells, and also the hematocrit, and mean corpuscular volume (MCV), was higher in the exposed than the unexposed group. But the average count of monocytes, erythrocytes, hemoglobin and hematocrit did not have a significant difference [13].

In different laboratory studies performed on animals, controversial results were reported about the effect of steady magnetic fields on blood factors. The results of some studies shows increases in different classes of white blood cells, red blood cells and hemoglobin concentration which is not in line with the results of this study [14]. But the results of some studies showed decreases in the count of lymphocytes and increases in the count and average volume of platelets, which are in line with our results [15, 16]. In some other lab-based studies the parameters related to red cell counts did not change either [2, 3] and this was in line with the results of this study. Controver- 
sial results are seen in regard to the other parameters related to red blood cells and there are few similar human studies to compare with. It seems like these dissimilarities between studies maybe due to different intensities and durations of exposure to magnetic fields.

\section{Conclusion}

It seems like exposure to steady magnetic fields even in permissible levels may lead to adverse effects on workers' blood indices. Occupational exposure to magnetic fields may lead to decrease in some types of white blood cells, and increase the count and volume of platelets. Therefore, more research is needed in order to further improve the working conditions of these workers.

Due to the controversial results, there is still no conclusive evidence for denying or proving the negative health effects of steady magnetic fields. In reports about the adverse health effects of magnetic fields, the relative risks were mainly not high and the effect of confounding factors such as nutritional status makes decision making difficult. Therefore, still more research should be performed.

\section{Acknowledgment}

The authors wish to thank the Research and Development Manager, Mr Saied Ghasemi, the Senior Research Officer Ms Afsar Eslami, the Head of the Safety and Health unit Dr. Majid Saadloo and all of the employees of this industry who cooperated with us in this research.

\section{References}

[1] International Commission on Non-ionizing Radiation Protection (ICNIRP), Health Phys. 96 (2009).
[2] M. Elferchichi, H. Abdelmelek and M. Sakly, Turk. J. Hematol. 24 (2007).

[3] M. S. Zaghloul, J. Am. Sci. 7, 8 (2011).

[4] World Health Organization, Static fields Geneva: World Health Organization (2006).

[5] A. J. Swerdlow, Report of independent Advisory Group on Non-ionising Radiation.static magnetic fields. London: Health Protection Agency (2008).

[6] M. Feychting, Prog. Biophys. Mol. Biol. 87, 2 (2005).

[7] American Conference of Governmental Industrial Hygienists (ACGIH). Threshold limit values for chemical substances and physical agents and biological exposure indices. Cincinnati (2011).

[8] R. Hokmabadi and M. Esmaelzadeh Kavaki, Radiation Safety and its Complications. Tehran: Arvij Iranian Publications (2013) pp. 45-56.

[9] S. Derahkshan and M. H. Bagherzadeh, Oncology and Hematology, Hematopoietic Disorders. In: Harrison TR, editor. Principles of Internal Medicine (Translated). Tehran: Hayan (2012) pp. 35-60.

[10] J. L. Marsh and T. J. Armstrong, Am. Indust. Hyg. Asso. J. 43, 6 (1982).

[11] A. Vyalov, Springfield, Virginia: National Technical Information Service Report No JPRS 63033 (1974).

[12] A. Choobineh and F. Amirzadeh, Indian J. Occup. Environ. Med. 9, 2 (2005).

[13] A. Fani, A. Moeini, M. Haidari Bateni, I. Fani, A. Chehrei, and P. Fani, Journal of Shahrekord University of Medical Sciences 7, 4 (2005).

[14] A. Salem, A. Hafedh, A. Rached, S. Mohsen, and B. R. Khémais, Pharmacol. Rep. 57 (2005).

[15] D. M. Djordjevich, S. R. De Luka, I. D. Milovanovich, S. Janković, S. Stefanović, S. Vesković-Moračanin, S. Ćirković, A. Ž. Ilić, J. L. Ristić-Djurović, and A. M. Trbovich, Ecotoxicol. Environ. Saf. 81 (2012).

[16] C. Sihem, A. Hafedh, S. Mohsen, P. J. Marc, and B. R. Khmais, Turk. J. Hematol. 23 (2006). 